\title{
Holy Communion as Public Act: Ethics and Liturgical Participation
}

by

\author{
Bruce T. Morrill, S.J.*
}

\section{Introduction}

During the 1990s, the discipline of liturgical theology in North America witnessed multiple constructive attempts at articulating the intrinsic relationship between the church's ritual celebration of worship and the irreducible ethical dimension of the life of faith the gospel demands. The efforts spanned the ecumenical spectrum, with notable book-length treatments by Methodist Don Saliers ${ }^{1}$ and Roman Catholic Kevin Irwin ${ }^{2}$ appearing in the same year (1994) and offering similar arguments for the necessity of adding to the patristic adage lex orandi, lex credendi a third element-lex vivendi (or agendi)_-so as to clarify that the "law of belief" established by the "law of prayer" is not a matter of merely asserting doctrinal concepts but, rather, an agenda for living. The first two volumes of Lutheran Gordon Lathrop's trilogy ${ }^{3}$ framed the moment, while my own attempt at integrating political and liturgical theology through the ethical-memorial character of the eucharist ${ }^{4}$ reached publication at decade's end. Common to all four of us authors was the influence of the Russian Orthodox Alexander Schmemann, whose tight little corpus of passionate prose pressed for a recovery of Christian liturgy's primordial purpose as revealing an entire vision of life, as his still widely-read book For the Life of the World puts it. ${ }^{5}$ Schmemann traveled the globe tirelessly until his early death to

* Dr. Bruce Morrill is Professor of Theology at Boston College; as of August 16, 2011, he will be the Edward A. Malloy Professor of Catholic Studies at Vanderbilt University. He may be contacted at bmorrill@sjnen.org. This paper was originally given at the conference "Liturgy, Ethics, and the Interpretation of Vatican II" held at and sponsored by Boston College in March 2010.

${ }^{1}$ Don E. Saliers, Worship as Theology: Foretaste of Glory Divine (Nashville: Abingdon, 1994).

${ }^{2}$ Kevin W. Irwin, Context and Text: Method in Liturgical Theology (Collegeville, Minn.: Liturgical Press, 1994).

${ }^{3}$ Gordon W. Lathrop, Holy Things: A Liturgical Theology (Minneapolis: Fortress, 1993); and Holy People: A Liturgical Ecclesiology (Minneapolis: Fortress, 1999).

${ }^{4}$ Bruce T. Morrill, Anamnesis as Dangerous Memory: Political and Liturgical Theology in Dialogue (Collegeville, Minn.: Liturgical Press, 2000).

5 Alexander Schmemann, For the Life of the World: Sacraments and Orthodoxy, rev. ed. (Crestwood, N.Y.: St. Vladimir's Seminary Press, 1997). 
cancer in 1983, answering invitations to speak, not only to Orthodox audiences but also to a great variety of ecclesial bodies, on the content and form of the liturgy as the key to embracing life in this world as God's project, the kingdom of God. And yet, he repeatedly bemoaned how the import of his message missed the mark of his largely enchanted listeners (and readers). While writing my doctoral dissertation and in the first years of my professional career thereafter, I found my lectures-so deeply inspired by Schmemann and his ecumenical followers-often falling upon a similar fate. I recount one such tale at the outset here so as to introduce the basic problem and its corollaries that comprise my current wrestling with the relationship between liturgy and ethics.

\section{Liturgy and Ethics: Sweeping Theory versus Practical, Particular Questions}

A couple of years after completing my Ph.D. at Emory University and taking my faculty position at Boston College, I received an invitation from Holy Spirit Catholic Church in Atlanta to give a talk for their Sunday morning adult education series - a long running, strongly attended program impressive for an American Catholic parish. The deacon who contacted me said that they would like for me to discuss the eucharist, and I, in turn, asked if they had any particular aspects of the mass in mind. Receiving the reply that no, the approach was up to me, I decided to exploit the name of their parish, entitling the talk: "Liturgy of the Church: Work of the People, Work of the Spirit." The lecture would unpack Vatican II's recovery of the concept of liturgy as a participatory action of the assembled church, as well as the promise - pastoral, ethically formative, ecclesial, and ecumenical —of recognizing the agency of the Holy Spirit in the roles and actions of all assembled, as opposed to the clergy imaging Christ to the observant laity. Such would, in my estimation, amount to a lecture that would expand the knowledge and stretch the imaginations of these parishioners-something both interesting and challenging for them. I wanted: (1) to press the traditional roots of the revised Mass of Paul VI, (2) to demonstrate the work of the Spirit in proclaimed word and shared sacrament as shaping the practical lives of faithful participants, and (3) to expound on the ecumenical character of such a pneumatological understanding and practice of the liturgy. Such were the goals and contours of my Sunday morning lecture, whose content and style were in the encompassing theological genre of Schmemann and others whose liturgical theologies I had found so inspiring.

Here is a one-paragraph summary of the ethically-formative vision I elicited from rejuvenated liturgical tradition. 
The key to the ongoing reform and renewal of the Church's liturgy lies in practicing it as a privileged, indeed singular, form of knowing and experiencing the freedom of the gospel. Christians today must come to the table of God's word and the eucharist ${ }^{6}$ not to confirm uncritically the ways in which our society tends to measure our importance and self-worth (such as incomes, houses, automobiles), but to open ourselves over and again to the Spirit of Christ who reveals through scripture and sacramental tradition how we are Christ's body now in the world. The sacrament of confirmation makes us subjects of the eucharistic action, changing us from passive observers of a religious ritual into active participants receiving anew, during every eucharistic prayer, the power of the Holy Spirit invoked both on the bread and wine and upon those who have assembled to share it. If the sacramental rites of the Church make use of a wide array of sacred objects, symbolic gestures, and ritual personages, this is not to make those who have assembled passive observers of a religious spectacle but, rather, to reveal to them the divine glory that is hidden in every human body and shared among all people of good will (see Luke 2:14). This evangelical-ethical approach to liturgy is a challenge for all in the Church today, but one worthy of the baptism in which all have been immortalized for lives of Christ-like service, in love with the world that he came to save and will one day return to gather into a new heaven and a new earth (cf. Rev 21:1; 2 Pet 3:13).

The hundred people comprising my Sunday morning audience gave me a nice round of applause, after which I invited questions. First off the mark: "Father, why can't my wife, who is Methodist, receive communion with me when she comes to mass? And why am I not supposed to take communion when I go to her church?" Many heads immediately nodded, people turning briefly to each other in enthusiastic anticipation of my reply. It was a question-cum-statement that truly gave me pause. The people had patiently listened to my sweeping, fervent vision of liturgy and life as world-transforming mission, it seemed, so as finally to get to ask the theologian what really mattered to them: the Roman regulations restricting access to holy communion. These middle-to-upper-class New South Catholics, so regular in mass attendance and supportive of their pastor and extensive parish staff, had highly practical, pastoral-really, critical-concerns about the relationship between liturgy and life that I had simply not anticipated. I had sought to inspire the folks with an appreciative knowledge of the elements of the rite that could open into new awareness for participation, but what was on many of their minds was the boundary cutting off such participation with and for the very people with whom

\footnotetext{
${ }^{6}$ Dei Verbum 21.
} 
they sacramentally share their Christian vocations, namely, their wives and husbands. ${ }^{7}$

I decided that the first thing needed in reply was a presentation about the facts of Roman Catholic Church polity (canon and liturgical law), so that all in the room might be aware of the official ecclesial parameters of the problem. But I suspect that to my audience those comments sounded like the massive shift in methodology from my biblically-, patristically-, and ecumenically-inspired talk that it was. The questions kept coming, pressing me to explain the history of schisms and the Roman Catholic doctrine of apostolic succession and the necessity of union with the bishop of Rome. I suspect many in the room already knew some or all of that, while others did not, but I could also sense that I was struggling to get at the heart of what these practicing Catholics experienced as the fundamental question about liturgy and ethics: The dignity of every person-perhaps, even more pointedly, of all the baptized - goes on the line in the communion procession.

As I have continued to reflect on the discussion I shared with the Holy Spirit Church parishioners, I have been trying to conceive how liturgical theology (secondorder theology) can adequately take account of-indeed, may need to give priority to-the contexts of celebration in theorizing about liturgical practice as formative of Christian ethical agents. Ecclesiology - a highly practical, historically-situated ecclesiology oriented to the ritual body-must be addressed when arguing (with the use of traditional and historical texts) for what the Spirit of the crucified and risen Christ offers believers through liturgical participation in the paschal mystery. Attention to the particular elements of rite that actually grasp the imagination of the faithful comprise one good starting place.

Over the past decade the communion procession (access to holy communion) has emerged as a key test case for popular theologizing about liturgy and ethics in the American Catholic Church. Functioning on interpersonal and local levels as a problem for "mixed marriages," the ecclesial-ethical dilemma of eucharistic participation has taken on a wider societal character in the electoral cycles of the American political system. I am referring here, of course, to the strategy of various U.S. Catholic bishops publicly declaring that specific candidates for governmental office are banned from receiving holy communion in their dioceses. The reason for the prohibition is the inconsistency of the candidate's legislative record and campaign platform with the church's official teaching concerning abortion. As public figures, those politicians embody-function as personae of - the principles, values, and affections not only of the United States but also, at least in the eyes of the

${ }^{7}$ Lumen Gentium 35, 41; and Gaudium et Spes 48-50. 
Catholic hierarchy and some laity, of the church as well. Scandal-a serious threat to the health of the social body of the church, those bishops are effectively arguing - is at issue, and thus cannot be ignored. In many cases the bishops also declare their pastoral responsibility to call to repentance the politician, whose eternal soul is in danger. Still, many (often even the majority of) U.S. Catholics, as scientific polling data of election results indicate, do not judge these Catholic politicians in the same way. Indeed, their criteria for what constitutes scandal are quite different. Imbued with varying degrees of what social theorists describe as communitarianism and liberalism, many protest - some in print, far more in conversation-that the bishops are politicizing the public office holder's faith, which is properly a personal matter.

Stepping back here, in the forum of an academic essay, I would argue that this question of ecclesial discipline and sacramental polity is rightly political - a politicized issue-because the liturgy of the church itself is a type of political act. Here I shall draw upon the work of Bernd Wannenwetsch, a German Lutheran ethicist at the University of Oxford, to elucidate something of the political dimension of Christian worship before turning to historical and anthropological evidence for the communion procession as a particularly powerful element of the eucharist, because constitutive, in part, of the moral agency of the members of the church.

\section{Liturgical Worship as Political Practice, as Ethical Socialization}

Setting aside conventional modern notions of politics, Wannenwetsch argues that the church's liturgical worship is "inescapably political," for in assembling to engage in word and sacrament its members are "transposed into a social order ... aligned towards the recognition of the good that comes from God, towards the common exploration of the good in the world, and towards the trying and testing of that good in shared action." 8 Worship is a non-foundational ethical source for the lives of the faithful, for it is participation in liturgy itself that forms their perceptions, imaginations, and judgments according to the ethos of the revelation of God. Upon this ethos of God's judgment and actions experienced in the liturgy theological ethics can reflect, bringing its conceptual implications to bear upon the issues and decisions the faithful engage in their daily lives and larger world. But it is, nonetheless, in the enactment of the assembly itself, the communio they

${ }^{8}$ Bernd Wannenwetsch, Political Worship: Ethics for Christian Citizens, ed. Oliver O'Donovan, trans. Margaret Kohl (New York: Oxford University Press, 2004) 9. 
share, ${ }^{9}$ that the members of the church "find a specific, social form of life" that is "their basic political existence." 10

While scholarly and popular Christian ethics enlist multiple sources for reflection and judgment (scripture, history, philosophies, etc.), the liturgy plays a uniquely important function on account of its own way of bringing the canon of scripture (which Wannenwetsch acutely notes "was established precisely for the requirements of worship") and others of those same sources together to construct "a comprehensive sensory, intellectual, and spiritual experience. This is worship as a form of life." 11 No autonomous exercise of reason at one's desk, worship is socially dramatic as it continuously wrestles with the pathos and ethos ${ }^{12}$ of life:

[W] must remember that worship is not a linear, harmonious socialization process, in which the ethical shaping of believers follows like words written one after another on a blank page. Ethical learning always proceeds in the form of a struggle between the "old" and the "new" man. As Paul says in his famous paraclesis at the beginning of Romans 12 , it is a matter of the new morphe of the Christian life.... Although "the form of this world" is destined to pass away ( 1 Cor 7:31), he evidently, for all that, assigns it to the effective formative powers which put an almost irresistible spell on human beings. Even Christians are not always free of their influence; they need the reminder (the "consoling admonition": paraklesis) of their freedom in Christ. These "proofs of God's mercy" (oiktirmoi, Rom 12:1), which Paul has talked about in the previous chapters, must be continually kept before eyes and ears. So the transformation required is expected and promoted not by an iron will but emphatically through the "renewal of your mind," the nous as the organ of perception in the widest sense-practical judgement. ${ }^{13}$

Whereas Wannenwetsch draws primarily on Paul's Letter to the Romans here, liturgical theologians (myself included) have most often turned to 1 Corinthians 11 , Paul's admonition of their eucharistic assemblies, as a primordial source for the

\footnotetext{
${ }^{9}$ Wannenwetsch employs but does not elaborate on this crucial concept. For constructive treatments and bibliographies, see Bernard J. Cooke, "Body and Mystical Body: The Church as Communio," in Bodies of Worship: Explorations in Theory and Practice, ed. Bruce T. Morrill (Collegeville, Minn.: Liturgical Press, 1999) 39-50; and Bernard J. Cooke, The Distancing of God: The Ambiguity of Symbol in History and Theology (Minneapolis: Fortress, 1990) 287.

${ }^{10}$ Wannenwetsch, 7.

11 Ibid., 14.

${ }^{12}$ See ibid., 37. The affinity of Wannenwetsch's thought and philosophical resources (including Wittgenstein) with that of Don Saliers (whom he nowhere cites) is most evident in this conceptualization of pathos and ethos in liturgy. See Saliers, 21-38.

13 Wannenwetsch, 37.
} 
eucharist's meaning and purpose. Allow me to revisit that Pauline text yet again, for it surely anchors eucharistic tradition as intrinsically social and ethically oriented. ${ }^{14}$

What we find in 1 Corinthians 11 is not only one of the earliest definitions of tradition in the church but also one of the first teachings about the eucharist. Paul is able to hand on (v. 23) to the Corinthians the origin of the church's eucharistic meal in Jesus' words and gestures at the supper on the eve of his death. His passing on of the tradition is occasioned, nonetheless, by unacceptable reports about their assemblies. Paul perceives the conventional social behavior of the wealthier Christians as defeating the very action of communion in the body and blood of Christ that they should be enacting. Paul instructs the wealthier members to recognize what they are doing when they feast together while the poorer members, lacking the time and money to join, feel humiliated. Such selfish feasting betrays a character inimical to that of Christ, whom the community claims to commemorate in the performance of the Lord's supper. The failure to discern the body of the Lord that brings condemnatory judgment upon them (v. 28) is not, as has so long been the anachronistic interpretation by Roman Catholics, a matter of recognizing the real presence of Christ in the bread and wine but, rather, of abandoning their society's standards so as to conform their lives to Christ's. Faithfulness to eucharistic tradition requires a discernment of Christ's body in its many members, just as Paul will write later in Romans 12. The practical recognition of the dignity of each person comprises faithful proclamation of Christ's death in the worship gathering and shapes how believers are to live until he comes again (v. 26). ${ }^{15}$ Paul's explanation of the liturgical tradition amounts to an exhortation that the community be more authentically what they are called to be or, as Augustine later put it, that they become the body that they receive, the sacrament of the peace and unity achieved by Christ. ${ }^{16}$

But while the substance of the eucharistic tradition as a fraternal sharing perdured from the apostolic period through Justin up to and with Augustine, the ritual form of its practice changed during those ensuing centuries, and inevitably so, it would seem, because of the exponential growth in church membership by the early fifth century. Gathering around the table of a shared meal in house churches morphed into processing to the front of the basilica to receive the body of Christ from

${ }^{14}$ For discussion of the passage with reference to the works of Xavier Leon-Dufour and Jerome Murphy-O'Connor, see Bruce T. Morrill, "The Struggle for Tradition," in Liturgy and the Moral Self: Humanity at Full Stretch Before God, ed. E. Byron Anderson and Bruce T. Morrill (Collegeville, Minn.: Liturgical Press, 1998) 68-71.

${ }^{15}$ On the performative character of proclamation (kataggelete), see ibid., 70.

${ }^{16}$ See J.-M.-R. Tillard, Flesh of the Church, Flesh of Christ: At the Origins of the Ecclesiology of Communion, trans. Madeleine Beaumont (Collegeville, Minn.: Liturgical Press, 2001) 40, 42. 
the ordained minister. Bernard Cooke's comprehensive thesis for how a threefold (philosophical, hierarchical, and ritual) distancing from the God experientially shared by the first generations of believers in Christ gathered momentum by the fourth century is borne out here by the fact that fewer and fewer baptized members of the church joined the communion procession at all. ${ }^{17}$ This is complex history, of course, but some attention to the procession and reception of communion down the ages (a method Robert Taft has promoted ${ }^{18}$ ) can be instructive about the social and thus ecclesial perceptions of human dignity, active membership in the church as Christ's body, and assurance of salvation/redemption in comparison and contrast to our contemporary situation.

\section{Offering and Communion Processions: A Historical Survey}

In his historical survey of eucharistic rituals, sermons, and practices from the fourth to eighth centuries, Robert Cabié highlights two types of practices whereby the faithful who came forward for communion maintained the identification of their lives with that of Christ, as well as with the lives of their fellow assembled believers. One was the requirement that all communicants bring food from their tables at home to present to the ministers, portions of which (bread and wine) would be designated for eucharistic communion while the rest would be used to feed the poor and the clergy. The dignity entailed in the donation is evident in the oft-repeated reminder of the Council of Elvira ( $c a$. 300) that the bishop should receive such offerings only from those who would be sharing in the communion rite. ${ }^{19}$ Homiletic evidence across several centuries and regions indicates that the rich were not to communicate in the eucharist at the expense of the poor. While the actual means of delivery ranged from an unremarkable depositing of the gifts in the sacristy in Gaul to the hymned and incensed clerical procession with the people prostrating as the gifts passed in the churches of the East (the origins of the Orthodox "Great Entrance"), another type of procession developed in Africa and acquired detailed description in the Roman Ordo I: At the beginning of the liturgy of the eucharist, the people brought their offerings-bread and wine, food and tithes-forward to the ministers before or even up to the altar table. Thus, the

${ }^{17}$ See Cooke, The Distancing of God, 37-56.

${ }^{18}$ See Robert Taft, "The Structural Analysis of Liturgical Units: An Essay in Methodology," Worship 52.4 (1978) 314-29.

${ }^{19}$ See Robert Cabié, The Eucharist, ed. A. G. Martimort, trans. Matthew O'Connell, The Church at Prayer, vol. 2, (Collegeville, Minn.: Liturgical Press, 1986) 82. 
liturgy entailed two processions of the people accompanied by psalms with antiphons, one for bringing forth the fruits of human labor and the other for receiving the mystical body of the Lord. Cabié recounts, "St. Augustine sees in this double procession an expression of the 'marvelous exchange' represented by the incarnation: Christ takes our humanity in order to bestow on us his divinity."20

Such a theological reality comes only (to echo Louis-Marie Chauvet ${ }^{21}$ ) at the mercy of the body, that is, the divine grace comes only through the anthropologically powerful experience of processing amidst a specially assembled body of people. The import of that assertion can be illustrated by recounting the contemporary case of one particular performance of the post-Vatican II liturgy. The qualities of the processions in this one community's Sunday mass reflects the Council's radical reorienting of the mass as an active participation in the Christ's paschal mystery, as opposed to the post-Tridentine gazing at the transubstantiated host so as to receive something of the "fruits" of the clerically executed and consumed blessed sacrament. The objective of the reform (putting in official motion that of the Liturgical Movement) was to recover the full engagement of all in the liturgy, as enactors of the ritual symbolism, the source and summit of the people's ongoing lives as the ethical, social, interpersonal work of human sanctification, of salvation. Such realization of the gospel in the practical workings of the world is, according to primordial Christian tradition, the very glory of God.

In 1994 I visited Loyola University of New Orleans for some days of relaxation between writing doctoral dissertation chapters. To my Sunday morning inquiry about a good place to go to mass the men in the Jesuit dining room recommended St. Augustine's, a parish in one of the city's poorest, most troubled neighborhoods. I made my way there, parked my car amidst the broken glass of the street, and joined the almost entirely African-American congregation for what proved an exuberant two-hour liturgy combining the Mass of Paul VI with the music, bodily and vocal prayer styles, and preaching patterns of African-American Christianity. Most arresting and memorable for me were the two processions of the entire assembly framing the liturgy of the eucharist, which began with every member-old and young, women, men and children - coming up the main aisle to deposit their donations in a large basket at the foot of the altar, singing and dancing with the choir's anthem. Bringing up the rear were elders and children bearing bread and wine.

${ }^{20}$ Ibid., 78.

${ }^{21}$ See Louis-Marie Chauvet, The Sacraments: The Word of God at the Mercy of the Body (Collegeville, Minn.: Liturgical Press, 2001). 
I was witnessing the type of procession about which I had read in Cabié's historical study, and I was deeply affected, especially as I experienced the impact on the second procession for communion, how much more communal and consecratory and empowering it felt because of its mirroring the first corporate movement. The proclamation of Christ in word-of the Jesus tempted by Satan yet triumphant in sticking to God's ways (for it was the First Sunday of Lent) - -became written on the bodies of all Christ's members, whose identification with him they expressed in the twofold procession pattern. I do not mean to romanticize that congregation in their dignity amidst the poverty of racism, drug violence, and so forth. But the revelatory character and impact of that liturgy for those participants, in the myriad joys and concerns they had brought and convictions of purpose they took away, seemed undeniable. And I would argue that, however somatically bland the single communion processions in the Anglo-American Catholic parishes may be in contrast, still the act of processing one by one amidst a ritual body as one writes a deep, polyvalent, uniquely personal message on the bodies of all. The robust practices Latinos are bringing to U. S. Catholicism, of course, would provide much for further reflection on procession. ${ }^{22}$

But how did that get lost? By the ninth century in the Latin churches the people's donations from their own tables was fading fast and then vanished with theologians' condemnations of the use of leavened bread for the eucharist. The procession disappeared, and the preparation of the gifts became the provenance of the clergy in the sanctuary, one of many factors by the tenth century contributing to the decline in the people's participation in the eucharist. As for the communion procession, Cabié reports, "As a matter of fact, at a very early period the faithful fell into the habit of approaching the Lord's table only rarely, and it was judged better to let non-communicants leave" after the Lord's prayer and before the fraction rite. ${ }^{23}$ In sixth-century Gaul, Caesarius of Arles ordered that the faithful stay until the Our Father and then receive a blessing, while Gregory of Tours spoke of the communion rite occuring "after the dismissal." That tripartite blessing/ dismissal remained a widespread practice through the Middle Ages, and it aligns with the repeated evidence that communion by the laity was a rarity. When twelfth-century theologians and mystics led revivals of lay communion at mass, the clergy had no idea how to minister the sacrament in the context of a regular parish mass, so that liturgists "then had recourse to [inserting] the ritual used in

\footnotetext{
${ }^{22}$ See, for just one example, Roberto S. Goizueta, Caminemos Con Jesús: Toward a Hispanic/ Latino Theology of Accompaniment (Maryknoll, N.Y.: Orbis, 1995).

${ }^{23}$ Cabié, 116.
} 
communion of the sick." 24 With rare, scattered exceptions, any ritual vestiges of the mass as communio, as fraternal sharing fostering fraternal charity, and, thus, of the eucharist as a corporate, communal experience shaping the social-political imagination and judgments of the people, were gone.

Not that people stopped judging one another. The citizens of Western Christendom did so, however, by other social conventions. Cabié gives this account of the seventeenth century: "Abstention from Communion was so much a part of local mores that those who wished to communicate would do so after the crowd had gone, lest they appear to be "flaunting themselves.'" 25 Thus developed the early morning "communion mass" for the pious laity who could receive out of the view of the rest of the faithful, whom they would join later at the main parish mass. Liturgical historian James White observes:

It may seem an anomaly today, but well up into the twentieth century Communion was not normally given to the people at what is assumed to be the appropriate moment, after the Communion of the priest, but before, after, or from a side altar at any point during the Mass . . . to kneeling communicants, who interrupted their devotions during the Mass to receive from a priest not engaged in the Mass. Our sense of Communion as an integral part and climax of the community's actions would have amazed most eighteenth-century worshipers. ${ }^{26}$

The content and vigor of Pius X's reforming efforts for the eucharist - his mandates for early and frequent communion and the endorsement of the Liturgical Movement's scholarship valorizing the active participation of all the faithful in the liturgy - truly set a new course for the church's eucharistic practice in the twentieth century. The reform mandated by the Second Vatican Council's Constitution on the Sacred Liturgy further altered the overall ritual space of the mass, giving the people a greater sense of entitlement to participation, helping create the ecclesialliturgical environment for the contemporary controversies over receiving communion in the U.S. Catholic Church.

\section{Ritual and Moral Agency in Contemporary U.S. Catholicism}

If the scandal in earlier eras was a matter of individuals having the gall to present themselves for holy communion at the main altar during a regular parish mass, the conventional social and religious mores of American Catholics today run in

${ }^{24}$ Ibid., 167.

${ }^{25}$ Ibid., 178.

${ }^{26}$ James F. White, Roman Catholic Worship: Trent to Today, rev, ed. (Collegeville, Minn.: Liturgical Press, 2003) 37, 61. 
the opposite direction. Attend just about any mass anywhere around the United States and one will find that it is the odd person in the congregation who does not join in the communion procession. So great is the individual felt need not to be left out of the communal action that pastoral ministers have had to instruct and develop for those not in "full communion with the Catholic Church" the ritual accommodation of crossing their hands over their breast to indicate to the communion minister that they desire a "blessing" in place of receiving the consecrated host. People with youngsters bring them along in the communion line even though they have not yet received their first holy communion, with the young ones often reaching for the host the parent is receiving. The little children's actions (their expectations that they should get a "cracker" too), however unwittingly (or perhaps intuitively), symbolize the attitude of the vast majority in the assembly: "All are Welcome" (as a widely popular opening hymn by that title repeatedly proclaims).

Here we have a fine example of what sociologist of religion Jerome Baggett describes as the most common interpretive practice of tradition among U.S. Catholics of all classes and ethnicities today: negotiation. His summary analysis (toward the end of his recent substantial book synthesizing extensive fieldwork, data, and scholarly sources) warrants quotation in full:

An outcropping of what Michele Dillon calls the enhanced "interpretive authority" among Catholics (officially legitimated by Vatican II), negotiating with the broader tradition basically means appropriating those meanings proper to it in ways that best coincide with one's own sense of self. People speak of "my faith" because, aware of the religious agency they have grown accustomed to exercising, they think of their religious identity as a product of their past choices and future goals, both of which can be quite individualized. Cognizant that others have made different choices and mapped out dissimilar life goals, they highlight their nonjudgmentalism and religious unknowing by refusing to enter the tabernacle of ultimate "Truth" and preferring instead to linger within the outer portico of what is true "for me." Less sure of what they know, they tend to focus on how they act as a means of identifying themselves as Catholic, and they then monitor their actions to determine whether they are (or are likely to become) a "good person." Finally, they undertake this negotiation process in conjunction with-often in resistance to-an institutional church that, while generally setting the parameters of their religious agency, most parishioners understand as simultaneously necessary and fraught with serious shortcomings. ${ }^{27}$

27 Jerome P. Baggett, Sense of the Faithful: How American Catholics Live Their Faith (New York: Oxford University Press, 2009) 216. 
Baggett immediately continues his next paragraph: "These themes appear again and again as Catholics go about rooting themselves within their tradition in a way that feels authentic to them." ${ }^{28}$ Although Baggett at no point considers it in his own descriptions and analyses, the communion procession strikes me as a particularly powerful ritual-symbolic practice of what he identifies as the "tolerant traditionalism" characterizing a vast majority of American Catholics-a highly individualistic, constructive clinging to the faith while purposely refraining from judging the faith of others. ${ }^{29}$ The now ubiquitous popular approach to the communion procession, I would aver, enacts publicly that highly personalized, mutually accepting manner of belief, the ethos of the "people's church" that collides head on with that of the "bureaucratic church" of the clerical hierarchy, which church historian Jay Dolan observes as seemingly "ever more intent on imposing discipline and exerting control over the faithful." 30

The hierarchy perceive the sacraments-but really, the eucharist predominates here-as means of grace for the benefit of those who are in the state of grace, that is, with no awareness of having committed gravely immoral acts that are the matter for discerning serious sin within the rite of penance. Since 1973 the U.S. Catholic bishops have made abortion the singular, nonnegotiable moral issue taking precedent over all others in society, ${ }^{31}$ with Pope John Paul II advancing this same singularity of abortion's evil in his encyclical Evangelium Vitae. ${ }^{32}$ Not surprising, then, are the public prohibitions from communion that the more institutionally rigorous U.S. bishops decree against Catholic politicians who support legal abortion. Not surprising, either, given the late-modern ambiguity between public and private, are the seemingly contradictory explanations the bishops tend to give in their press releases, asserting that the matter of presenting oneself for holy communion is a personal affair and a private matter the bishop is addressing only to the politician for the sake of his/her soul-even as he makes it a cause célèbre in his diocesan newspaper and the wider, exponentially more powerful organs of the commercial news media. Not surprising, finally is the reticence of the large majority of U.S. Catholics to judge these politicians or anybody else for joining in the communion procession, nor the vitriolic clamor of the small but highly vocal ultra-conservative

${ }^{28}$ Ibid.

${ }^{29}$ See ibid., 235.

${ }^{30}$ Ibid., 238.

${ }^{31}$ See Margaret Ross Sammon, "The Politics of the U.S. Catholic Bishops: The Centrality of Abortion," in Catholics and Politics: The Dynamic Tension Between Faith and Power, ed. Kristin E. Heyer, Mark J. Rozell, and Michael A. Genovese (Washington, D.C.: Georgetown University Press, 2008) 11-26.

${ }^{32}$ Evangelium Vitae 58. 
Catholics whose integralist-traditional approach to the religion sees in these publicized issues of ethics and belief genuine scandal and controversy. With absolutely no intention of sarcasm here, one can ask whether and how the act of processing to and receiving holy communion in a church or cathedral today can be parsed into private and public components. This honest question returns us to the very nature of the Catholic Church's reformed liturgy itself, the structure and form and content of which the theologians of the Liturgical Movement intended to renew the engaged participation of all so as to empower their putting the faith they experience in the ritual to work in the world their baptisms have charged them to cultivate and serve.

The "bureaucratic church," to employ Dolan's terminology, insists upon proper moral and doctrinal self-examination as the ethical obligation prior to approaching the eucharist, with the nearly singular doctrinal matter being a certain conceptualization of the real presence of Christ in the host-yet another contested issue worrisome to the bishops since at least the early 1990s, when a poorly worded (in my judgment) New York Times poll found the majority of U.S. Catholics choosing a "symbolic" understanding of the eucharistic elements. The "popular church," in contrast, seems largely to consider participation in the liturgy itself as the ethically — or better yet, as Wannenwetsch argues, the ethico-politically-formative experience during which the members of Christ's body, the church, encounter their Lord in assembly, presiding minister, word, and sacrament. ${ }^{33}$ That Sunday mass now tends to last an hour that is evenly divided between the liturgy of the word and the liturgy of the eucharist would seem to be a reality that, over time, has tacitly brought about a significantly reflexive engagement ${ }^{34}$ with scripture for those who attend regularly. Even though homiletic preaching started from scratch in the late 1960s and has yet to gain a satisfactory level of quality (according to all ongoing polling data of practicing Catholics), still, it seems that the people's hearing the full complement of all four canonical gospels over the three-year lectionary cycle and annual Easter cycle has been a significant practice affecting how they imagine and bodily approach the eucharistic table. Over the years people hear accounts of Jesus feeding hungry multitudes, receiving criticism for dining with sinners, suffering remonstration from his own disciples for allowing a penitent woman to bathe and anoint his feet at table, and telling parables depicting the reign of God as a banquet populated by social outcasts and nobodies. Over and again when I find myself in conversations with the faithful about access to holy communion,

\footnotetext{
33 Sacrosanctum Concilium 7.

${ }^{34}$ For a discussion of how the social theory of reflexivity informs late-modern Catholics' approach to tradition, see Baggett, 231-37.
} 
including those at Holy Spirit parish in Atlanta years ago, I am consoled to hear them readily and easily referring to those stories and images of their Lord with great conviction (which Baggett identifies as contemporary U.S. Catholics' original negotiation and innovative working with the Bible, among several of the religion's key traditional resources). ${ }^{35}$ This cannot but be a vital sign of a faith in good health, because practically engaged, regularly exercised.

\section{Conclusion}

On the other hand, American Catholics' religious nonjudgmental attitude coupled with staunch resistance to "whatever influence the church might have in controlling people through fear and guilt" or "being 'told what to do," is, as Baggett himself acknowledges, troubling: "That is, if the 'good news' truly is simply a freedom to reject even the most carefully discerned judgments that conclude 'this is right and this is wrong,' then this may ultimately prove disempowering to church communities by undermining their capacity for meaningful ethical deliberation and consensus building." 36 Toward the end of the carefully argued conclusion to his book, Baggett perceptively recognizes that the way American Catholics, as Americans, struggle with their ethical-religious questions is in terms of the individual self:

How does one determine what is most authentic to oneself? How can one come to some certainty when adjudicating between what the institution should carry on and what it should cast aside? How good does one have to be to be good? In addition to cultivating tolerance, how does one truly understand the value of being Catholic and devoted to Christ in a religiously pluralist world $?^{37}$

Telling to this liturgical theologian, nonetheless, is the way, at least to my reading, sociologist Baggett does not include the liturgy as a key traditional source-indeed, I would argue, the very site-for creatively and productively bridging the divide between modern autonomous individuality and modern rhetoric and yearning for a communal, ethically transforming experience (practice) of church. His research methods, questions, and conclusions run along the lines of individuals wrestling

35 "[Catholics] rely heavily on the cultural tools handed down to them by their tradition when reflecting on the world around them. They draw from the Bible, church teachings, priests' homilies, and conversations with people they trust" in making "judgments about which doctrines are central or peripheral to the faith, which symbols seem meaningful or calcified, which features of the institutional church merit their devotion or disdain, and which aspects of the surrounding world are sacred or profane" (ibid., 233).

36 Ibid., 220.

37 Ibid., 236. 
with biblical and doctrinal material as texts to study and discuss. I am arguing, however, that the experientially, practically different medium of engaging those sources in the liturgy, as Wannenwetsch as well as many liturgical theologians have argued, is the practice wherein the faithful, however unevenly or inarticulately or increasingly only occasionally, continue to work out the meeting of gospel and lived convictions in the company of others purposefully assembled in the presence of Christ.

Elsewhere ${ }^{38} \mathrm{I}$ have written on the resistance of American Catholics, including many of the ordained, to engage the significant amount of prophetic and judgmentoriented texts that appear annually in the liturgical year's lectionary cycle (widely choosing, for example, excruciatingly banal songs irrelevant to the proper seasons). I end here only able to acknowledge the complexity of the phenomenon that liturgy as ritual is, but with the conviction that scholarly study of such elements as the communion procession-examined in synchronic and diachronic ritual and contextual detail-promises descriptive and prescriptive contributions liturgical theology can offer a rapidly, drastically changing church. ${ }^{39}$

38 See Bruce T. Morrill, "The Beginning of the End: Eschatology in the Liturgical Year and Lectionary," Liturgical Ministry 12 (Spring, 2003) 65-74.

39 "One iteration of American Catholicism has clearly ended, but another has begun. Less dogmatic, exclusive, and institutionally dependent, as well as typically far less sure of its own bearings, it is hardly less religious than what has preceded it" (Baggett, 239). 